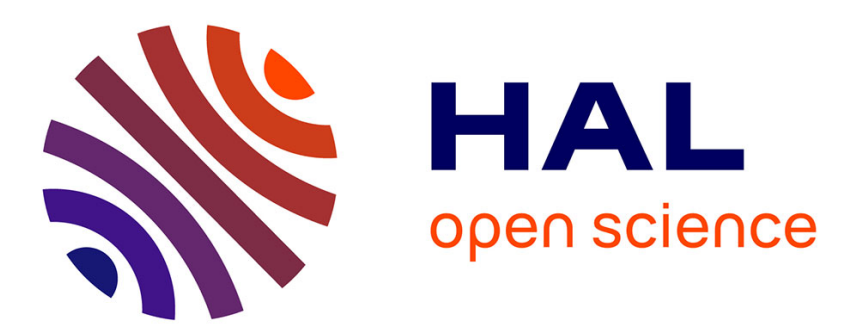

\title{
Between Repression and Cultural Opportunities: The Emergence of a Contentious Movement in Cuba after the Fall of the Berlin Wall
}

Marie Laure Geoffray

\section{- To cite this version:}

Marie Laure Geoffray. Between Repression and Cultural Opportunities: The Emergence of a Contentious Movement in Cuba after the Fall of the Berlin Wall. From Silence to Protest, 2014. halshs01726636

\section{HAL Id: halshs-01726636 \\ https://shs.hal.science/halshs-01726636}

Submitted on 8 Mar 2018

HAL is a multi-disciplinary open access archive for the deposit and dissemination of scientific research documents, whether they are published or not. The documents may come from teaching and research institutions in France or abroad, or from public or private research centers.
L'archive ouverte pluridisciplinaire HAL, est destinée au dépôt et à la diffusion de documents scientifiques de niveau recherche, publiés ou non, émanant des établissements d'enseignement et de recherche français ou étrangers, des laboratoires publics ou privés. 
Chapter 13

Between Repression and Cultural Opportunities: The Emergence of a Contentious Movement in Cuba after the Fall of the Berlin Wall

\section{Marie-Laure Geoffray}

The fall of the Berlin wall seemed to open a new political era in Cuba. Thousands of Cubans who studied in the Soviet Union and Eastern Europe were sent back home. Although most still supported socialism, they were deeply influenced by Mikhail Gorbachev's reform politics and wished that Cuban leaders would choose the same path. They contributed to the already lively debates taking place on Cuban campuses, in cultural institutions, as well as in some research centers. The political conjuncture seemed all the more favorable since, in order to prepare for its Fourth Congress, the Cuban Communist Party launched in 1991 a call for a national debate about the future of socialism in the country, and the government legalized the dollar in 1993 and allowed tens of thousands of citizens to leave the country in 1994 after massive street protests, whereas emigration had always been associated with counterrevolution.

But this moment characterized by more freedom of speech and organization came to an abrupt end in March 1996 when Raúl Castro declared that critics of the socialist model would no longer be tolerated. The Center for the Study of the Americas, a well-known research center for politics and economics, was especially targeted because of its central role in the ongoing debates about the future of socialism in Cuba. It was shut down and its scholars relocated to other places of work. Many artists and intellectuals went into exile and the cost of protest increased dramatically. Nevertheless, contentious groups kept emerging and organizing in the second half of the 1990s. How can we account for this persistence of protest?

The cost of collective action in an authoritarian context is generally much higher than in other contexts. To explain mobilization in autocracies, scholars have often emphasized the fact that people anticipate future gains linked to regime change (Oberschall 1973). But costs and benefits cannot always be predicted (Geddes 1995; Loveman 1998), especially in authoritarian contexts where repression is more systematic, violent, and often arbitrary. In such contexts, mobilizing resources is also difficult because of the intensity of state scrutiny on autonomous social and political action and on the financial support received from abroad. This is why the political opportunity structure (POS) approach could be seen as especially relevant to understand the possibility of protest in such contexts.

A few years after Oberschall (1973: 114) had stressed that social protest generally emerges when authoritarian states loosen their control on society, Tilly (1978), McAdam (1982), Tarrow $(1989,1994)$, and Kriesi (1995), considered - albeit in democratic contexts the variation of mobilizations' intensity by linking them to the opening of the structure of political opportunities. For Tarrow (1994: 85), opportunities depend on the degree of openness of political institutions; the stability of political alignments; the existence of divided elites; and the possibility to strike alliances with influential allies. Kriesi (1995) further refined the model by adding such variables as the organization of the state (degree of territorial centralization, concentration of state power, cohesion of state bureaucracy), elites' tactics (formal and informal) vis-à-vis challengers, and the degree of repression (see also McAdam, 1996: 26-29).

The POS approach was especially successful because almost any political variable could fit into the model and contribute to explain - ex post - variations in mobilization patterns. That is also why it was criticized as being either too structural (marginalizing 
elements of political conjuncture and the subjective apprehension of political situations) or too elastic, if both structure and conjuncture are taken into account (Gamson and Meyer 1996; Mathieu 2002). Although the scholars who coined and defined the notion of the POS mitigated the structural and objective perspective of their approach by stating that opportunities need to be visible and perceived as such in order to lead to mobilization (McAdam et al. 2001), the structural bias of the notion remained problematic for many scholars (Siméant 1998; Mathieu 2002; Fillieule 2005). Mathieu (2002: 81-82) discusses the fact that social movements are seen, in this perspective, as determined by the State and not the other way around, whereas he argues that social movements should be understood as relatively autonomous from political parties and from the State. A good case in point is Kurzman's thesis (1996), quoted by Mathieu, according to which the Iranian Revolution was not produced by the opening of the political structure, but rather by the belief, among opposition movements, that they had become stronger. Other empirical examples give evidence that a closed POS does not always prevent movements from organizing, since "initiator" movements can pave the way for other "spin-off movements" (McAdam 1995).

Beyond the objectivist and structuralist biases of the POS perspective, its focus on large processes, so as explain protest cycles, does not allow us to understand more micro interactions between protesters and state authorities. It also does not allow us to consider protesters' perceptions and interpretations of their local environment, in which their actions are embedded and in which they calculate and anticipate risks. In authoritarian contexts, protesters' calculations are especially constrained by their fear of repression. Although "configurations of power" (Kriesi et al. 1995: 53) do exist, they are not organized around shared political positions (like the parties of the left and the social movements studied by Kriesi and his colleagues in Western Europe) within a system structured by broader cleavages. In Cuba, such configurations are based on fluctuating dynamics of implicit and explicit negotiation between protesters, who intend to expand the existing space for dissent and push for social and political pluralism, on the one hand, and State agents, who strive to maintain a unified discourse and ideology without nevertheless risking social upheaval, on the other. These configurations open up a space for action, which we can be understood as a "game" (Elias 1991: 157) between protesters and authorities. All parties become players in the game and respond to each other's "moves". By playing the game, players become interdependent both as allies and as opponent, thus creating shifting configurations of power.

In authoritarian contexts, the configuration of this "game" is especially constrained because repression is more intensely exerted than in democracies (Davenport 1999, 2004) and it is especially effective to help governments stay in power (Escriba-Folch 2013). Scholars thus stress that repression is one of the most robust variables of the POS approach (Loveman 1998; Johnston and Mueller 2001; Earl 2003). Following Earl (2006), I refer to Tilly's definition of repression as "any action by another group, which raises the contender's cost of collective action" (Tilly 1978: 100). In other words, I argue that we must take into account not only state repression but also the social control of protest, either exerted by the state or by other actors. In Cuba, I consider that in order to understand how protest may emerge we must also analyze how repression is carried out because repression is an essential dimension of the State's wielding of power. Firstly, the State security apparatus creates a ubiquitous feeling of threat, even when there is no direct repression. Secondly, the limits given to civil and political rights prevent people from organizing freely and openly. Finally, open repression (physical and psychological violence or imprisonment) creates negative emotions, such as fear or apathy, and deters people from mobilizing. Now, one must bear in mind that when repression actually works - that is when protest is completely suppressed - it becomes invisible in such 
contexts (Earl 2004; Combes and Fillieule 2011). That is why softer repression mechanisms like the "channeling" of contention should be studied, so as to understand better how protesters manage to carve out a - limited - space for action (Earl 2003, 2004, 2006).

The objective of this chapter is to study the changing dynamics of the configuration of power in authoritarian Cuba so as to show the relevance of a multi-level analysis of the relationships between protesters and the State. ${ }^{1}$ Context thus matters, but we need to understand it with a relational perspective (Mathieu 2001, Goodwin and Jaspers 2003, Fillieule 2005). Institutional arrangements are not determinants of protesters' action, but part of the game played by both parties. Rather, institutional arrangements structure both discourses elaborated on such actions and the spaces and social sectors in which these actions develop. The cultural sphere was, for instance, often a freer space under Cuban and other socialist regimes all over the world because of the ambiguity of both the artistic and intellectual media and messages (Feher et al. 1983). Furthermore, Cuban political elites channeled young contentious voices into the cultural sphere, which allowed them to control and monitor them better, while isolating them from political dissidence. This chapter will first trace the emergence of contentious collectives ${ }^{2}$ in the second half of the 1990s in Cuba. It will then show how those contentious dynamics were channeled into the cultural sphere. Finally, it will indicate how this channeling impacted on the way protest was voiced and how it constrained its development. I focus here on three specific collectives, out of dozens which emerged in Cuba at the turn of the 2000s, because of their already established existence (more than ten years), the relatively low turnover of their core groups, and the fact that they managed to obtain some official recognition from the Cuban state: Joven Cuba (which later became the BASTA, ${ }^{3}$ Cátedra Haydée Santamaría, and then Observatorio Crítico), a collective of young students, professors and intellectuals; Omni Zona Franca, a collective of self-taught artists and performers; and the hip-hop movement.

\section{Protesters in Quest of Meaning}

Cuba is relevant as a case study because contention was almost fully eradicated during the first thirty years of socialist rule and then it re-emerged after the fall of the Berlin Wall. The agents of this renewed contention were, furthermore, generally weakly resourced. Young, often black or mixed race, unevenly educated and residents of poor or suburban districts of Havana, they were not predestined to converge and organize in order to contribute to social and political change in their country. When they did, they were met with censorship and repression. Although some collectives disbanded and many of their members left the country; others adapted, locating their activities within the more permissive cultural sphere, especially in the cultural centers of disadvantaged neighborhoods. I now propose to give a brief presentation of the protesters and of the process of their convergence into contentious

\footnotetext{
${ }^{1}$ This chapter is based on over eleven months of ethnographic fieldwork, which I conducted for my doctoral dissertation on contentious collective action in Cuba between 2005 and 2010. I systematically participated in the collectives' activities and in its members' daily lives. I conducted comprehensive interviews with all of the core members of the collectives, as well as the relevant political and cultural State agents, which were in charge of negotiating with them, either at the local level or at the national level.

${ }^{2}$ The groups of young Cubans which I studied are neither associations nor trade unions. The way they organize is best characterized as informal, variable and flexible but they constitute collective endeavors, which are oriented towards social and political change. This is why I chose to name them contentious "collectives", following Kaufmann and Trom's definition (2010: 9): flexible entities with "multiple modes of inter-individual aggregation."

${ }^{3}$ Brigada de Acción Social contra el Totalitarismo y la Alienación - Brigade of Social Action against Totalitarianism and Alienation.
} 
collectives, so as to show the extent to which context can impact on people's trajectories at a micro level with consequences in terms of collective action.

\section{Loyalty as Inheritance, Rebellion as Necessity}

Scholars who study dynamics of protest in authoritarian contexts rarely focus on protesters' social backgrounds. ${ }^{4}$ Although I am not aware of such research in the Cuban case, it is essential to understand how recruitment to high-risk activism takes place in a context in which dissenting political opinions are systematically censored and often repressed. The revolutionary political socialization ${ }^{5}$ of Cuban protesters, as well as their exposure to the crucial international event constituted by the fall of the Berlin Wall when they had just come of age, are key elements to understand their engagement in protest activism.

Most members of the contentious groups who organized in Havana at the end of the 1990s came from modest families. ${ }^{6}$ Their grandparents were either peasants or workers, and their parents would certainly have had the same social fate if the social and political order had not been disrupted in 1959. Indeed, a small majority of families are either black or mestizos (mixed race), which made it difficult to climb the social ladder before the Revolution. The protesters' parents have thus fully benefitted from the social policies implemented by the revolutionary government, and especially from the anti-discrimination and free-access-toeducation laws passed in 1959. They became qualified workers, nurses, doctors, engineers, or civil servants. Thankful for the social progress brought about by the Revolution, they actively participated in the construction of the new political order. Many were also party activists, trade unionists (in the Central de Trabajadores de Cuba-Cuban Union of Workers - the only official trade union) or local political leaders (within mass organizations), and some even worked for the Interior and Defense Ministries. They shared a strong revolutionary ethos, which they strove to transmit to their children.

Despite this upward social mobility, the families - whose members later became involved in contestations - remained economically modest because of the egalitarian distribution of wages under Cuban socialism. They still lived in the poor neighborhoods and the suburbs of Havana when the Berlin Wall came down in 1989. With the disintegration of the Soviet Union, the flow of subsidies and importations from the Soviet Bloc, on which Cuba heavily relied, stopped abruptly. With the economic crisis which followed, these neighborhoods became more marginalized and the families experienced a drop in social standing. When the dollar was legalized in 1993, the families I surveyed did not benefit from its legalization because they did not work for the growing capitalist sector and had no family relatives abroad who could send remittances. Their children were thus faced with the difference between their parents' continued revolutionary ethos and their actual experience of loss (of economic resources, of political orientation, of socialist values, and of friends and family who emigrated). Whereas some of the future members of the collectives were already rebellious against a system, which they felt discriminated against them racially and socially (many were school dropouts), others were excellent students and conformed socially and politically. But for all of them, the fall of the Berlin Wall and the consecutive disintegration of

\footnotetext{
${ }^{4}$ Exceptions include Sigman (2009), Cuadros (2011) and Geoffray (2012).

${ }^{5}$ Socialization refers to "the comprehensive and consistent induction of an individual into the objective world of a society or a sector of it" (Berger and Luckmann 1966: 150).

${ }^{6}$ I systematically gathered data on the interviewees' social background (parents' and grandparents' social origins, types of jobs, Cuban Communist Party membership, political opinions and political responsibilities, religion and beliefs, cultural capital, place of residence, number of children). The interviewees' biographical sketches can be found in Geoffray (2012: 333-52).
} 
the Soviet Union provoked a disruption of their social routines, life trajectories, and expectations for the future. Feelings of disorientation is thus what eventually led them to look for spaces of experimentation and self-expression which allowed them to coalesce into emerging contentious collectives.

\section{Generational, Cultural and Spatial Logics of Convergence}

The experience of loss triggered different responses in young Cubans. Some dropped out of school and became delinquents; others started illegal businesses, while a group of high school students created journals and workshops to debate the new social and political conjuncture. The expression of their rebellion thus initially took different paths, mostly depending on their school achievements and their degree of political (in)conformity. What could then trigger the convergence between the students who read Foucault and Adorno and aspired to become intellectuals despite the economic crisis, and the much less well-educated young workers who engaged in illegal practices (including black market activities) and expressed their anger through rap songs or graffiti?

With the disintegration of the Soviet Bloc in the early 1990s, Cuba entered a period characterized by a severe economic crisis. This meant that whole sectors of the Cuban economy stopped working altogether. Public transportation was scarce. Social control was no longer carried out systematically. Although the future members of the collectives needed to engage in informal economic activities to survive, they also had extra time to spare. They were biographically available ${ }^{7}$ and eager to share their feelings of loss and anger with their peers. But in a vast city like Havana and, at a time of crisis, there were very few places where young people could meet, have fun, and debate all at the same time. When a few musicians and rap aficionados organized parties so as to create such places, they were immediately successful (Perry 2004; Fernandes 2006: 90). And, when in 1994, Rodolfo Rensoli, an older rock musician from Guiteras - one of the marginalized, eastern suburbs of Havana - managed to find support from local cultural authorities to create a rap festival, large crowds started gathering in the official venues lent by the cultural authorities of Alamar, the nearby town with cultural facilities suitable for large events. The cultural centers of those suburbs, as well as a few places in Centro Havana, a run-down district in the center of the city, thus transformed into hot spots where the youth met so as to exchange ideas, get to know the new artistic trends, have fun, and spend some of their leisure time among like-minded people ${ }^{8}$. The University of Havana and some research centers also worked as places of convergence, although mostly for students and intellectuals. Protagonists of earlier contentious dynamics ${ }^{9}$ (the few artists and intellectuals who did not leave the country in the 1990s) acted as mentors for their younger counterparts. They created these spaces, found institutional support and strong allies among political or cultural figures who could intercede for them in case they were censored or repressed.

Recruitment into the collectives took place in these specific places through dyadic relations between friends or contacts, that is between people who already entertained "strong ties" (Passy 2003) based on trust. Trust was especially important in the Cuban authoritarian context in which people feared repression and State agents' constant arbitrariness. Members

\footnotetext{
${ }^{7}$ Biographical availability is defined as the "absence of personal constraints that may increase the costs and risks of movement participation, such as full time employment, marriage, and family responsibilities" (McAdam 1986:70).

${ }^{8}$ Geoff Baker (2006:215) argues that rap developped as a « response to recent changes in the physical and social fabric

of the Cuban capital », thus linking the sociospatial crisis to the emergence of the movement.

${ }^{9}$ Especially ex-members of Pensamiento Critico (1967-1971), the Center for the Study of the Americas (CEA) and Paideia (1988-1990).
} 
of the collectives were often childhood friends, couples, high school mates, and neighbors who had known each other for a long time and who had shared feelings of distress and anger throughout their common experience of loss. One of the interviewees expressed it in the following way:

I am with people who think like me, who want the same things that I want, who dream the same dreams that I dream. That is fundamental. (...) the group is the only place I have to know about what is going on in Cuba (...) to discuss things, to grow up. (Barbara, Joven Cuba/BASTA/Cátedra, September 2007)

Social and political activism thus organized within micro, social milieus with very strong bonds. Those bonds allowed for some control of the inhibiting negative emotions such as stress, mistrust, and fear.

Despite their differences, the young Cubans who decided to engage in protest at the end of the 1990s can be considered as a "generation", not only because they were mostly born during the same decade (the 1970s), but also because their social trajectories were marked by a global event (Braungart and Braungart 1989), the disintegration of the socialist bloc, the consequences of which (economic crisis, loss of political orientation) struck them when they had just come of age. Context thus matters to understand how these young Cubans coalesced into contentious collectives at the end of the 1990s, although this convergence was rather counter-intuitive given their divergent social backgrounds, experience of the school system, and apprehension of politics before the early 1990s. But context matters inasmuch as it is articulated with these young Cubans' appropriation of a specific chain of events. In the case of the young Cubans studied here, the conforming young intellectuals met the rebellious nonconforming rappers and other would-be artists. The general crisis of the 1990s in Cuba pushed the former to move from a political position which legitimated the revolutionary government towards more critical and contentious ideas, whereas the latter progressively channeled their rebellion into artistic modes of expression of their anger, desires, and hope. This convergence was made possible thanks to their spatial convergence into Havana's few "alternatives" hot spots and to the decision made by the young intellectuals to adapt to what they interpreted as cultural opportunities ${ }^{10}$ for self-expression, social activism, and autonomous action from the State.

\section{Disconnected Conjunctures: Cultural versus Political Opportunities}

With Raúl Castro's speech in 1996 and the consequent crackdown on academics, the intellectual, artistic and political contentious collectives ${ }^{11}$ which had managed to gain some visibility and legitimacy dissolved. Their members either went into exile or stopped meeting. 1996 seemed to bring to an end to the protest episode which had emerged at the very end of the 1980s. Raúl Castro's speech sent a clear message that political challengers would not be tolerated. But almost at the same time, liberalization policies were implemented in the cultural sphere. While artists and intellectuals had been closely scrutinized until the 1990s, they were granted greater freedom of speech and travel and they were allowed to publish and exhibit

\footnotetext{
${ }^{10}$ I do not use the notion of "cultural opportunities" in McAdam's sense (1994) as "shifts in the cultural climate", but in a restricted sense, as opportunities for protest which arise from within the cultural sphere. ${ }^{10}$ Fernandes $(2006: 13)$ coined the notion of « artistic public spheres », in the Cuban context, so as to account for the "vibrant debate found in spheres of Cuban cultural life », but she does not engage in the debate about resistance and/or protest in authoritarian regimes (2006: 185). I do focus on protest dynamics, and on protesters' conflictive relationships with authorities, which are more often located at the margins rather than at the centre of the cultural sphere.

${ }^{11}$ Paideia, Hacer, la Campana, Arte Calle, Criterio Alternativo, or Tercera Opcion are some of the artistic and intellectual groups which emerged during those years and which discussed political and cultural alternatives to the Cuban socialist regime.
} 
their works abroad. The repression, which used to be implemented against critical artists and intellectuals (threats and harassment, prison, exile), was now deemed to be inappropriate. A new Minister of Culture, Abel Prieto, was appointed in 1997, and his job was to make the cultural sphere economically profitable and give it international visibility so as to lend a more creative and tolerant face to Cuban socialism (Fernandes 2006). The claims and demands, which had been voiced during the early 1990s and remained unanswered, were progressively channeled towards the cultural sphere.

\section{The Cost of Playing on an Uncertain Ground}

Despite Raúl Castro's crackdown, informal collectives and circles of political debate led by young students managed to survive under the radar because they were less visible and often consisted of friends, which made them barely distinguishable from non-political peer groups. They can be described as a "small contention" in a repressive state (Johnston 2006). Some of the most active, like Estatus No Quo, Criterio Alternativo, Joven Cuba (later BASTA, then Cátedra Haydée Santamaria, and today Observatorio Crítico) did organize to adapt to the new conjuncture, and started meeting in a somewhat "clandestine" way so as to become "invisible" (using their own words) to the coercive forces.

In the case of Joven Cuba, which I specifically studied, the meetings were restricted to well-known members only. New members were recruited through co-optation, and the collective organized in an informal and horizontal way so as to prevent its easy dismembering. These tactics worked, insofar as the collective never experienced direct State repression, but they also failed somehow because they generated feelings of fear and distress, which eventually led to a thorough transformation of the organization.

Joven Cuba was founded with two major objectives: to create a space for political debates and elaborate a political program; and to lead to "raise awareness rapidly among workers" in order to find allies and implement this program. For that purpose, its members elaborated a mode of action which they called "clandestine work". They wrote leaflets which they distributed widely so as to make their political positions known to workers and have them reflect on the political situation. At the same time, the leaflets were written with ironical undertones or as riddles so as to depart from the official political language. The following are a few examples: "Do not let them fumigate your mind" (fumigation campaigns against mosquitoes are common in Cuba); "Do you understand who is the real enemy?" (the government constantly called dissidents or the diaspora the "enemy"); or "Freedom is always the freedom of the one who thinks differently." The leaflets were signed BASTA, the subsequent name of the collective. They were distributed at dawn, when the streets were dark and empty, hidden in books (during the Havana Book Festival), under stones (on the routes taken by official demonstrations), in small cracks in walls of official institutions, or in toilets (when meetings or congresses were organized). But this mode of action was eventually abandoned after two episodes which created fear and paranoia in the group. It is important to describe these episodes at this juncture, because they show that uncertainty constrained contentious action more than repression.

The first episode was organized in order to protest against the election of the new president of the Federation of Students at the University of Havana which many students, including the members of the BASTA deemed to be fraudulent. The protesters wrote, printed, and distributed material in order to inform their fellow students about the situation and to urge them to mobilize against the new president. Soon, rumors spread that thousands of leaflets had circulated in Havana and in the rest of the country. Members of the group were terrified 
that their action had gained unexpected visibility and that they were going to be identified. But there were no consequences. The new president was officially elected and none of the members of the collective was threatened or repressed. Despite this lack of repression, they quickly disbanded out of fear and many left the city to visit their family in the countryside so as to "disappear" for a while. The second action consisted in a similar operation during the $28^{\text {th }}$ Congress of the Workers' Union in April 2001. The collective circulated short texts calling on workers to demand a true socialist democracy in which they would wield power. Again, this action had no consequences and the Congress took place without incident. But the collective almost collapsed because the members feared they had been infiltrated, despite the lack of evidence that such a thing had happened. Its members finally decided that their tactics failed because their actions had no impact, and they were too afraid to continue working along the same lines.

BASTA members could well have taken other types of decisions. The lack of repression could indeed have been interpreted as a positive element and pushed the collective in the opposite direction. It was their overwhelming feelings of uncertainty, as far as the limits of the possible which, on the contrary, led to a collective crisis. Their decision was thus not determined by external objective factors (such as repression) but by internal logics: group cohesion was shaken. ${ }^{12}$ It is relevant to observe that the reorganization of the collective's tactics was rather linked to their subjection to "constraints of power": since they did not know if and when they were under scrutiny, they started behaving as if they were under constant surveillance, as in Foucault's Panopticon (1975: 197-229). The arbitrariness of political crackdown in Cuba contributed to lend strength to this Panopticon effect. Nevertheless, we must bear in mind that the omnipresence of power in Cuba does not mean that it is effective (Kott 2002: 11). In the case of the BASTA, it is possible that the State security services simply did not detect their existence and modes of action, especially because most members of the collective were also friends, and sometimes couples, who also studied together at university.

We can conclude here that the political context was less of a determining factor in this case than the collective's isolation from other contentious endeavors and lack of resources. The members could not rely on collective memories of struggle because social and political struggles were virtually non-existent in Cuba since the 1960s (that is invisible to ordinary citizens because of the lack of non-official channels of information). And they could not appeal to allies who could have advised them because they were organized in a semiclandestine way, distrusted people who did not belong to their group, and consequently acted in an isolated fashion. Disorientation thus prevailed and led them to adapt their tactics. We can clearly see here how political opportunities matter less than the lack of more horizontal resources such as other contentious allies and incorporated resources (the ability to take decisions under stress, to manage fear, and to maintain group cohesion despite a hostile environment).

\section{Interpreting Differentiated Politics of Social Control in the Cultural Sphere}

While the BASTA worked underground, other collectives emerged and organized publicly. That was especially the case with the hip-hop movement and the collective of self-taught artists and performers - Omni Zona Franca. Both movements were hybrids because they were made up of young Cubans who were looking for some space to express themselves, to share their rejection of the dire social and political situation of the late 1990s, and to have fun with

\footnotetext{
${ }^{12}$ In a similar case, Jason Lyall (2006) links the failure of the Russian protest movements against the Chechen wars to its organizational culture rather than to state repression.
} 
their peers. Theirs was a kind of escapism from their grim daily lives characterized by hopelessness and deprivation. Both movements were concerned with freedom of speech, social control, growing social inequalities, racism and sexism, and with finding friends to share with, to have fun with, and maybe to be successful as self-made artists (this hope was mainly triggered by the attention they drew from foreign journalists, art curators, or music producers).

Hip-hop especially benefitted from the liberalization policies implemented in the cultural sphere. Whereas the older rock movement had undergone harsh censorship and repression when it emerged in the 1960s because it was deemed to be an importation of a capitalist American music genre, hip-hop was met with less rejection (Pacini Hernandez and Garofalo 1999: 22). Despite some censorship and close monitoring, national cultural authorities generally tolerated, and in many cases even supported, the emerging hip-hop movement (Fernandes 2006), thanks to cultural promoters (Baker 2005: 376) and black intellectuals' enthusiastic lobby in favor of what they understood to be a renewed form of black culture (Geoffray 2012: 192-200). Most rappers were granted the Hermanos Saíz (AHS) membership, ${ }^{13}$ the national cultural institution for young promising amateur artists (aficionados), and some even became professional artists in the newly created Rap Agency especially those who managed to reconcile hip-hop with revolutionary slogans and values (see Baker 2005). Official venues were made available to organize concerts, festivals, and workshops and funding and logistical support was offered for some of their activities.

Although this new spirit of tolerance was not unconditional, the lack of direct repression (harassment, threats, imprisonment) against emerging critical and alternative cultural movements (street art and street performances, electronic music, the humorous videos movement, etc.) convinced the BASTA to change tactics. Its members, especially, interpreted the integration of hip-hop and Omni Zona Franca - to which they felt close - into the cultural sphere as a sign that contention clad in a cultural guise was better accepted than blunt political criticism. They started organizing in the open and created alliances with cultural movements, so as to obtain recognition and protection. Rather than discussing political programs and the organization of political campaigns, they organized more culturally focused activities. They also participated in Omni Zona Franca's street performances, in the workshops about race, gender or alternative art which took place during the hip-hop festivals, and bonded with other movements, especially the race movement (with organizations such as la Cofradia de la Negritud /Brotherhood of Negritude, and the Abakua unions). ${ }^{14}$

Such collaborations were very profitable for the BASTA, whose members realized that they could express themselves in quite a radical way without being subjected to direct or violent repression. They also acknowledged that the visibility they obtained from their work allowed them to interact with many people, whereas their previous "clandestine" actions prevented them from communicating with the public they were supposed to reach. Finally, they started interpreting the support they got from local authorities as a sign of their mutual interdependence.

\footnotetext{
${ }^{13}$ The Asociación Hermanos Saíz (AHS, Hermanos Saíz Association) was named after two brothers, who were assassinated by Fulgencio Batista (the former Cuban president 1940-44 and 1952-59). It was created in 1986, in order to give a specific space to young artists, who had not become professional yet and could thus not be part of the UNEAC (Union de Escritores y Artistas Cubanos - Union of Cuban Writers and Artists), the official organization of artists and intellectuals). It was also open to members with high-level amateur practices. There is a national head office in Havana and regional branches in every province.

${ }^{14}$ Abakuas are exclusively male fraternities (originally also Black-only), organized during the nineteenth century in order to protect their members and struggle against colonial rule. They have created specific theatrical rituals and a secret language.
} 
The dire economic situation in Cuba in the 1990s ushered in a new era of mounting socioeconomic inequalities, which led to heightened territorial disparities. Whereas more than 90 percent of the population used to be employed by the State, those numbers quickly dropped to 70 percent; and whereas spatial mobility was extremely limited until the $1990 \mathrm{~s}^{15}$ the economic crisis, the rise of the black market and the remittances sent by the diaspora triggered the emergence of new dynamics of spatial mobility, both between the provinces and Havana and within the capital city itself. The traditional modes of social control, through mass organizations at work and in the neighborhood, were no longer effective (Aguirre 2002). The authorities could no more rely on them to curb the growth of delinquency, especially in the dilapidated housing complexes of Havana's outskirts. They coped with the situation by implementing specific social programs, as well as leisure activities for the youth, in specific underprivileged urban areas. These leisure activities were part of a bigger plan to create a "massification" of culture, that is to promote "authentic" Cuban art forms, against the importation of foreign cultures (Prieto 2000). These new cultural policies included the creation of a diploma of "socio-cultural studies" in local university antennas, the creation of local publishing houses, and the renovation of local cultural centers, especially in downtrodden districts where social problems accumulated.

But this program was a failure. The promotion of the "authentic" values of Cuban culture and of amateur art practices did not appeal to young people, who aspired to better levels of consumption, were attracted to globalized cultures and dreamed of emigrating to the United States. Local authorities were generally not very successful at organizing cultural activities, as planned by the national level, and they were confronted with growing levels of delinquency and violence, especially among the youth. This is one of the reasons why local authorities partly encouraged the contentious collectives to organize activities for the community. They "facilitated" - to use Kriesi's notion (1995) - the local implementation of the collectives. This explains how rappers and Omni artists managed to obtain the right to use local cultural venues to organize concerts, performances, workshops, and festivals.

Such support did not always stem from a political consensus between state agents. For instance, Fernando Rojas, the Vice-Minister of Culture, told me when I interviewed him, that he contributed to promote hip-hop (when he was still a local Union de Jovenes Comunistas (UJC, Union of Communist Youth) leader in Alamar and Guiteras because it was a "new kind of artistic culture" which had to be understood as "revolutionary", and moreover that it managed "to channel youth restlessness." "But most local party members did not share such views, however, and they remained convinced that rap or street performances were counterrevolutionary. They did let rappers and other local contentious artists organize their own activities because, they hoped, that such activities would keep local youngsters out of trouble and thus prevent them from turning into delinquents, vagrants, or prostitutes. As we can see, there were differing reasons which allowed rappers and other self-made artists to find support and expand their movement. Black intellectuals were interested in promoting a debate on racial issues and they felt hip-hop could help them make that debate legitimate. Local political leaders used their ability to channel this movement and give it a place, which fitted national

\footnotetext{
${ }^{15}$ This was mainly because it was prohibited to sell/buy real estate (exchange could work but involved months of negotiation with the housing bureaucracy) and because it was almost impossible to survive without the libreta (rationing card). The food and other daily life products that came with the libreta could only be collected at the specific bodega (state distribution office) which was the closest to one's residency. It was thus almost impossible to move without official authorization.

${ }^{16}$ Interview with Vice-President of the Ministry of Culture, Fernando Rojas - June 2007.
} 
political tactics, as a springboard for their political career. While others still simply resorted to the contentious collectives either to cope with difficult social situations, which they felt they could no longer control, or to enhance their local legitimacy (see Rowell 2002 and Spires 2011 for similar dynamics in the ex GDR and China) since they could not count on sufficient resources from the State to gain local political recognition from their constituents. Such relations between the collectives and State agents located the former within local configurations of power. Indeed, collectives used their local and social legitimacy among their public in order to gain bargaining power and expand their space for action, while local officials let them do so as long as they did not trespass some red lines such as contacting political dissidents or voicing clear political criticism of the Cuban leadership ${ }^{17}$. Those local configurations of power were relatively stable until some protesters crossed both red lines, in 2009 , by participating in a street demonstration (together with critical bloggers, and other contentious collectives) against violence in the center of Havana. Following that demonstration, Omni Zona Franca was especially subjected to repression (threats and harassment from State security services and the Ministry of Culture), because authorities thought they had organized the march. The local cultural authorities in Alamar were not able to vouch for them (they either decided to stop supporting the collective or their national hierarchy ordered them to do so). As a consequence, Omni Zona Franca was expelled from the local gallery where it had been situated since the end of the 1990s in Alamar.

Until 2009 though, and despite close monitoring (and sometimes censorship or mild forms of repression like threats), the collectives had clearly gained leverage at the local level. One of the interviewees put it this way:

We represent an alternative in case of political change for some people in the system to reform without radically transforming the system. (...) The current crisis with the youth is not a lie, UJC members are talking about it (...) and some of them ask for help. They say "we do not know what to do, help us." And it is true, there are many problems (...) and the only ones who can manage those problems are people in the cultural sphere. And Fernando Rojas is not the guy who is going to go and talk to the youngster next door. No, it is the local rapper. It is Omni Zona Franca. It must be somebody who is able to discuss, and that won't be the UJC. (Interview with Gabriela, Cátedra Haydée Santamaria - former Joven Cuba/BASTA -, February, 2008)

The collectives took advantage, therefore, of both the liberalization of cultural policies and the differentiated spatial politics of social control so as to expand and push back the frontiers of the possible and the do-able, without however risking too much or engaging in a "safe radicalism" (Kapcia 2000: 212; Baker 2005: 378). They located their activities in the cultural sphere, especially at the local level, because they perceived State agents' interest in new youth behaviors and cultures. They thus developed a pragmatic sense to seize concrete opportunities for action within specific spatial contexts. Following Kriesi (1995) who took territorial centralization as a key variable of the POS and Earl (2003), who stated that the "identity of the repressive agent" matters, I suggest that both the territory in which contention takes place and the role played by the local elites do matter. But they do not matter in the

\footnotetext{
${ }^{17}$ Yvon Grenier (2011) proposes to distinguish between what he calls "primary" and "secondary parameters". According to him, critics are tolerated if they address the secondary parameters (mistakes which have been recognized as such by the Cuban leadership or the necessity for the Revolution to live up to its original ideals), but they are not tolerated if they address Fidel or Raul Castro, the Revolution or the dogma of unity. Although it is stimulating to try and think what type of criticism is tolerated or not and when it is tolerated or not, I believe that arbitrariness often makes it difficult to distinguish red lines from, say, orange lines. The sanctions taken against intellectuals like Roberto Zurbano (who lost his position as director of the publishing house of Casa de las Américas in 2012 (a famous cultural institution in Cuba) or Esteban Morales (who was excluded from the Communist Party in 2010) after they published articles which were critical of racism (Zurbano) and corruption (Morales) in Cuba testify to this difficulty. (Both racism and corruption had been denounced by Fidel Castro himself prior to Zurbano's and Morales' criticism).
} 
sense that State agents would be loosely connected to the national political elites (as is the case in the decentralized United States as studied by Earl), but because local and sectorial authorities are explicitly given some latitude by their national hierarchy to deal with the protesters, so as to face the differentiated effects of the socio-economic crisis on territories in Cuba.

\section{Socialization into the Norms of Tolerated Protest}

At the beginning of 2000, the three collectives (rappers, Omni Zona Franca and the Cátedra) managed to gain local and sometimes national recognition thanks to their institutional membership in the Asociación Hermanos Saíz (AHS). But while this recognition of their activities lent them visibility and access to certain resources, it also institutionalized the collectives, in the sense that it meant that the protagonists had to respect and assimilate rules, knowledge, routines, and roles (Lagroye 2002: 148-49). The insertion of the collectives' activities into cultural institutions created a new regulation of those activities. They were now obliged to respect the official norms of artistic creation and what was deemed to be the proper use of the resources given to them. Cultural authorities and legitimate intellectuals and artists in the cultural sphere contributed to create a "tangle of incentives" (McCarthy et al. 1991), which forced the members of the collectives to delimit the scope of their public activities carefully. This self-censorship in turn contributed to isolate "social" contention from "political" dissidence and helped the authorities reserve the use of coercion - which can be costly for Cuba's international image - mainly for political dissidents. These mechanisms of regulation, with logics of "facilitation" (Kriesi 1995) and "channeling" (Earl 2003), are not sufficiently taken into consideration, because they are less visible than other mechanisms, but they are nonetheless essential in order to understand how protesters can carve out a space for their protest activities and to see the extent to which these activities are actually constrained. Indeed, this "protest control" can structurally affect the way protest emerges, organizes, expands, or retreats as well as protest outcomes (Earl 2004: 77).

\section{Regulation through Norms}

The collectives' entry into cultural institutions compelled them to adapt to their norms. In its search for respectability, the BASTA changed its name and became the Cátedra Haydée Santamaria. ${ }^{18}$ The Cátedra now mainly organized cultural activities, or at least activities, which were presented as such. The hip-hop movement was also clearly constrained. Because rappers' entry into the cultural institutions was individual, (whereas Omni Zona Franca and Cátedra Haydée Santamaria were accepted as collective "projects"), they were especially vulnerable to the official norms of the cultural institutions.

Whereas competition between rappers had taken place in a horizontal way (reputation was linked to prowess in terms of verbal flow), it started to be organized in a vertical way: rappers now competed with each other with the objective to integrate the prestigious AHS. Auditions were organized and the selection board was composed of intellectual and artistic figures (writers, musicologists, historians, literary critics), who knew little about rap, and were generally selected by the national board of the AHS for their expertise in racial issues. The winners were thus rappers whose lyrics and rhythms were inspired by the Cuban traditional black music (batá drums, son) and who endorsed black aesthetics (use of conchas - seashells,

\footnotetext{
${ }^{18}$ Cátedra means "chair" and Haydée Santamaria refers to a revolutionary heroin who committed suicide. This fact makes the reference subtly contentious.
} 
boubous, braids). On the contrary, rappers who were inspired by American hip-hop (noisier, with scratches, and more repetitive rhythms), and for whom the flow and the protest load of the lyrics mattered more, were marginalized. In order to enter the AHS, the latter - the most numerous at the beginning - needed to adapt to the norms of "aesthetic quality" promoted by the selection board. In this sense, the channeling was co-produced both by State agents, who strove to create "institutionalized channels" (Oberschall 1973: 245) for the expression of social protest, and by legitimate but critical intellectuals and artists, who were interested in expanding their own influence within the cultural sphere and in Cuban society as a whole, and thus looked for respectable allies to co-opt.

Most of the rappers I interviewed for my research told me they found these selection boards to be illegitimate, but none actually called for a boycott of the auditions. On the contrary, many of the rappers who were unanimously recognized as influential and inspired within the hip-hop community were invited, little by little, to be part of these boards. They were thus put in a position in which they were given influence and power, which in turn meant that they needed to play the same game as the other members of the board, that is they needed to judge their fellow rappers according to aesthetic criteria. The responsibility given to these rappers had two effects: they had to engage into vertical relationships with cultural authorities, which contradicted the horizontal relationships they entertained among themselves; and they became socialized to the norms of tolerated criticism within the cultural sphere. The racial issue constitutes a good case in point. It was accepted to criticize racism as the historical inheritance of five hundred years of colonialism, but it was not accepted to consider it as a political problem which had not been dealt with (or worse, (re)produced) by the revolutionary leadership. In the cultural sphere, critics were thus tolerated as long as they were not interpreted by Cuban authorities as too "political"19. Artists played the game because they were offered opportunities for professionalization, i.e. official "recognition" (Grenier 2011:156).

Whereas rappers apparently aspired to work collectively so as to create spaces for expression and to protest against the existing social and political order, the more some rappers became professionalized, the more the movement actually split into sub-groups with differing codes, norms, and aspirations. Those who had managed to become professional rappers strove to keep their artistic status and to improve it (rap still enjoyed a low reputation as an artistic genre). Those who integrated the AHS but who could not eke out a livelihood from their music felt torn between their wish to become professionals and their understanding of hip-hop as a means of self-expression and social protest. Finally, those who did not manage to enter the AHS had a hard time adjusting to the new hegemonic artistic norms and they either radicalized or disbanded. Although this partition was rather the result of the channeling of rappers towards cultural institutions than an intentional dismemberment by political authorities, the consequences (heightened competition between rappers, emergence of artistic norms, Blackness as a central theme) benefitted the government, which constantly strove to isolate political dissidence from other forms of contention. The internal competition created by the possibility to professionalize successfully prevented rappers from interacting more intensely with other contentious and especially dissident movements ${ }^{20}$.

\section{Channeling through De-politicization}

\footnotetext{
${ }^{19}$ We cannot objectively distinguish between social and political criticism. Criticism becomes political when political authorities decide to classify it as such, and their decisions are often arbitrary on the matter. See Geoffray 2011: 42-45.

${ }^{20}$ There were exceptions like famous duo Los Aldeanos, Raudel (Eskuadrón Patriota), Ángel Yunier (El Critico)...
} 
We have expectations. We negotiate everything with the artists here. (...) Who they invite, which films are shown, we want to see the quality, etc. Because what matters to us is to produce quality culture for all. We cannot allow anything that has to do with pornography or terrorism. (M. A., culture manager at the municipal department of culture in Alamar, August 2008)

This excerpt of an interview I conducted with a local civil servant of the cultural department in Alamar (Havana) who dealt especially with the hip-hop movement and Omni Zona Franca, shows that the activities of the collectives are not always evaluated according to professional norms of "quality". Indeed, the criteria of professional quality remain vague in his speech and are not defined in terms of aesthetics. The references made to pornography and terrorism show that they are first and foremost moral and political. These same criteria are used against political dissidents and people in exile. They are stigmatized as "immoral", as "mercenaries", or as "terrorists" because they are associated with the American Central Intelligence Agency (and its counter-insurgency policies in South America). The use of such terms is very effective against the collectives because it is part of a larger discursive apparatus which creates constraints, inasmuch as it is based on a binary rhetoric: revolutionaries/counter-revolutionaries, patriots/mercenaries, who is not with us is against us. Dorronsoro (2005) calls this a "meta ideology of security" in the case of Turkey. This "meta ideology" constrains the possibility for protesters to use discursive resources which would stray too much from the official political framing of the Cuban reality. Although such a binary rhetoric creates gray zones (what does it mean to be a revolutionary?), it makes it difficult to voice a third opinion, which would be critical without siding with the dissidents, and asking for reform without calling for American intervention. Such a framing pushes towards depoliticization.

The collectives adapted to such discursive constraints. They used non-politically connoted terms to present their activities like trabajar hacia la comunidad (work with the community), buscar espacios de autonomía (look for autonomous spaces), favorecer el debate amplio sobre todo tipo de temas (generate large debates on all kinds of subjects), dar voz a lo alternativo (give a voice to what is alternative), contribuir a construir una "nueva Cuba" (contribute to create a "new Cuba"). They argued with State agents about the meaning of the "revolution", explicitly negotiated the possibility to take some of their activities to the streets, and looked for influential protectors in the cultural sphere who would vouch for them in case some of these activities were seen as being too "political". In order to secure that support, they constantly presented themselves as "convinced revolutionaries". Although that framing made sense for some who still believed in revolutionary values, it contributed to maintain a clear distance between political dissidence and social or cultural modes of protest. Poet Pablo Luis, a member of Omni Zona Franca, used it that way in an interview in September 2008:

There is a lack of dialogue between alternative movements and dissidents. It is because each one has its own strategies, each is busy with its own survival. (...) We work with institutions because we need them and because they need us. (...) And there is no alternative, we cannot say we are going somewhere else because everything here belongs to the state.

The use of delegitimizing tactics is thus the corollary of the logics of regulation of the collectives' activities through the norms of the professionalized cultural sphere. The containment of contentious practices (thanks to the imposed use of revolutionary semantics) is effective because it is articulated with the channeling of the contentious practices of the collectives towards the margins of the cultural sphere. The way authorities framed what represented a "quality culture" forcibly constrained those activities because it limited the accepted or tolerated ways of justifying their work. Although the collectives also sometimes 
broke the rules, they were pressured into using the same semantics as political authorities and to mitigate the protest dimension of their actions. This use of official semantics was ambivalent. On the one hand, it made the collectives' activities acceptable both to authorities and to audiences (neighbors, passers-by, artists, etc.) and it contributed to give them more visibility. On the other hand, the use of the revolutionary terminology lent legitimacy to the official framing of reality (Berger 1990) and reinforced the official dichotomy between those who are "with Cuba" and those who are "against Cuba".

Whereas rap songs, street performances, intellectual meetings and parties were the shapes intuitively chosen by young Cubans to express their anger and non-conformity with the Cuban political, economic, and social system at the turn of the 2000s, they became part of a broader tactical game. Their quest for recognition, which was first turned towards finding peers and voicing protest, articulated progressively with the possibility to professionalize, thanks to their gradual acceptance in the cultural sphere. Despite the fact that they continuously needed to argue with the authorities in order not to be categorized as "counterrevolutionaries", they managed to draw a distinction between contentious practices labeled as "social" or "community-oriented" which were somewhat tolerated, and political dissidence which was harshly repressed. In doing so, they managed to carve out some space for their activities and engaged in a win-win game with the authorities, who cautiously dealt with them, both because of the changing social situation and of international scrutiny. Although Omni Zona Franca and other members of the collectives now work hand-in-hand with the new blogger movement and sometimes even with dissidents, such logics of regulation and containment have long jeopardized the possibility to create a broad contentious movement which would acquire visibility, obtain the support of the general public, and thus be able to contribute to systemic social and political change in Cuba.

\section{Conclusion}

The Cuban case has allowed me to show that the POS approach, if understood with a structuralist and objectivist perspective, is not best suited to understand how contention can emerge in authoritarian contexts like Cuba where the political sphere remains (at least apparently) monolithic and hermetically closed to challengers. But the notion of "context" is key to an understanding of how protesters interact with their social, cultural, and political environment, both with State agents, other elites, and the general population. Variables of the POS approach remain relevant, such as the degree of centralized state control on all national territories as well as the cohesion of the bureaucracy (Kriesi 1995), if they are analyzed through the perceptions of the protesters. In the Cuban case, variations in the way social control is implemented in disadvantaged urban territories and the tactics of local elites to deal with protesters are elements of a game played by all parties within specific local configurations of power.

Protesters pragmatically calculate their chances of success according to their interpretations of concrete State policies. In that case, the semi-liberalization of speech within the cultural sphere as well as the spatial differentiation in the politics of social control have led them to locate their protest at the margins of the cultural sphere. These tactics have not gone unnoticed. Intellectual and artistic elites took advantage of the emergence of these politically acceptable forms of protest - which mixed social and political claims with an artistic and/or intellectual quest for identity, meaning and, recognition - so as to expand their own critical circles and accumulate social resources. National political authorities also managed the semi-opening of the cultural sphere so as to control emerging social protest and show a more tolerant face of Cuban socialism abroad, while local State agents resorted to 
negotiations with the collectives so as to keep up with changing social behaviors, which they could not monitor easily anymore, especially among the youth.

To expand on Earl's insight (2004: 61), political opportunities and repression are not only analytically distinct, but also cultural opportunities should be considered in authoritarian contexts so as to understand the possibility for protest despite the lack of space to do so in the political sphere, both from within the cultural sphere (Feher at al 1983, Popa 2001, Balasinski 2002, Fernandes 2006) and from its margins (Baker 2005 and 2006, Geoffray 2012). In such a configuration of power, arbitrariness does not disappear, but the constraints are most often routinized thanks to State agents' tactics of negotiating with protesters. This regulation is functional, because it is based on the implicit sharing of a revolutionary ethos between State agents, intellectuals and, protesters - which none really strives to deconstruct - because it helps them maintain the narrowing distance between political dissidence and a more "social" or "cultural" type of protest. In the Cuban case though, the transnationalization of protest, thanks to emerging contentious uses of the internet, has allowed to create bridges between "social" or "cultural" and political protest (Geoffray 2013). New alliances are currently emerging between the contentious collectives, intellectuals, bloggers and political dissidents, which could eventually lead to social and/or political upheaval in Cuba, as was the case in the ex-German Democratic Republic (Lüdtke 1998), in the ex-Soviet Union (Yurchak 2006), and more recently in Tunisia (Hibou 2011).

\section{References}

Aguirre, B. 2002. «Social control in Cuba », Latin American Politics and Society, 44(2), 6798.

Baker, G. 2005. Hip Hop, revolución! Nationalizing rap in Cuba, Ethnomusicology, 49(3), 368-402.

Baker, G. 2006. 'La Habana que no conoces'. Cuban rap and the social construction of urban space, Ethnomusicology Forum, 15(2), 215-246.

Balasinski, J. 2002. Culture et politique en période de transition de régime: le cas du theater en Pologne dans les années 1980 et 1990. PhD Dissertation. Université de Paris-Nanterre.

Berger, P. 1990. The Sacred Canopy. New York, Doubleday.

Berger T. and Luckmann P. 1966. The Social Construction of Reality: A Treatise in the Sociology of Knowledge. New York, Anchor Books.

Braungart, R. and Braungart, M. 1989. Les générations politiques, in Générations et Politique, edited by J. Crête and P. Favre. Ste. Foy (Québec), Presses de l'Université Laval, 7-51.

Chantraine, G. 2004. Par Delà les Murs. Paris, Presses Universitaires de France.

Combes, H. and Fillieule, O. 2011. De la répression considérée dans ses rapports à l'activité protestataire : Modèles structuraux et interactions stratégiques, Revue Française de Science Politique, 61(6), 1047-72.

Cuadros, D. 2011. La réactivation des mobilisations syndicales dans le Chili post-dictatorial: Trajectoires de militants communistes, in Voix de la Rue ou Voie des Urnes, edited by S. Déchezelles, and S. Luck. Rennes, Presses Universitaires de Rennes, 181-95.

Davenport, C. 1999. Human rights and the democratic proposition, Journal of Conflict Resolution, 43(1), 92-116.

Davenport, C. 2004. The promise of democratic pacification: An empirical assessment, International Studies Quarterly, 48(3), 539-60.

Dobry, M. 1986. Sociologie des Crises Politiques. Paris, Presses de la Fondation Nationale des Sciences Politiques. 
Dorronsoro, G. 2005. Mobilisations et régime sécuritaire, in La Turquie Conteste, edited by G. Dorronsoro. Paris, CNRS Editions, 13-30.

Earl, J. 2003. Tanks, tear gas, and taxes: Toward a theory of movement repression, Sociological Theory, 21(1), 44-68.

Earl, J. 2004. Controlling protest: New directions for research on the social control of protest, Research in Social Movements, Conflicts and Change, 25, 55-83.

Earl, J. 2006. Introduction: Repression and the social control of protest, Mobilization 11(2), 129-43.

Elias, N. 1991. Qu'est-ce-que la Sociologie? Paris, Editions de l'Aube.

Escriba-Folch, A. 2013. Repression, political threats, and survival under autocracy, International Political Science Review, 34(5), 543-60.

Feher, F., Heller, A., and Markus, G. 1983. Dictatorship over Needs: An Analysis of Soviet Societies. Oxford, Blackwell.

Fillieule, I. 2005. Requiem pour un concept: Vie et mort de la notion de structure des opportunities politiques, in La Turquie Conteste, edited by G. Dorronsoro. Paris, CNRS Editions. 201-20.

Gamson, W. and Meyer, D. 1996. Framing political opportunity, in Comparative Perspectives on Social Movements: Political Opportunities, Mobilizing Structures, and Cultural Framings, edited by D. McAdam, J.D. McCarthy, and M.N. Zald. Cambridge, Cambridge University Press, 275-90.

Geddes, B. 1995. Uses and limitations of rational choice, in Latin America in Comparative Perspective: New Approaches to Methods and Analysis, edited by P. Smith. Boulder, CO, Westview Press, 81-108.

Geoffray, M.L. 2013. Internet, Public Space and Contention in Cuba: Bridging Asymmetries of Access to Public Space through Transnational Dynamics of Contention. Desigualdades.net Working Paper Series, 42. (Available at http://www.desigualdades.net/Working_Papers/index.html) [accessed December 7, 2013].

Geoffray, M.L. 2012. Contester à Cuba. Paris, Dalloz.

Geoffray, M.L. 2011. Etudier la contestation en contexte autoritaire. Le cas cubain, Politix 93, 29-45.

Goodwin, J. and Jaspers, M. 2003. Caught in a winding, snarling vine: The structural bias of political process theory, in Rethinking Social Movements: Structure, Meaning and Emotions, edited by J. Goodwin and M. Jasper. Lanham, Rowman and Littlefield Publishers, 3-30.

Grenier, Y. 2011. Artistes et intellectuels cubains : entre incertitude et tâtonnements, in Cuba, un régime au quotidien, edited by V. Bloch and P. Letrilliart, Paris, Choiseul, 149-175.

Hibou, B. 2011. Tunisie : Economie politique et morale d'un mouvement social. Politique Africaine 121, 5-22.

Johnston, H. and Mueller, C. 2001. Unobtrusive practices of contention in Leninist regimes, Sociological Perspectives, 44(3), 351-75.

Johnston, H. 2006. Let's get small: The dynamics of (small) contention in repressive states, Mobilization, 11(2), 195-212.

Kaufmann, L. and Trom, D. 2010. Qu'est-ce qu'un Collectif? Du Commun à la Politique. Paris, Editions de l'EHESS.

Kapcia, A. 2000. Cuba: Island of Dreams. Oxford, Berg.

Kott, S. 2002. Pour une histoire sociale du pouvoir en Europe communiste: Introduction thématique, Revue d'Histoire Moderne et Contemporaine, 49(2), 5-23.

Kriesi, H. 1995. The political opportunity structure of new social movements, in The Politics 
of Social Protest, edited by C. J. Jenkins and B. Klandermans. London, UCL, 167-98.

Kurzman, C. 1996. Structural opportunity and perceived opportunity in social movement theory: The Iranian Revolution of 1979, American Sociological Review, 61(1), 153-70.

Lagroye, J. 2002. Sociologie Politique. Paris, Dalloz.

Linden, A. and Klandermans B. 2006. Stigmatization and repression of extreme right activism in the Netherlands, Mobilization, 11(2), 213-28.

Loveman, M. 1998. High-risk collective action: Defending human rights in Chile, Uruguay, and Argentina, American Journal of Sociology, 104, 477-525.

Lüdtke, A. 1998. La République démocratique allemande comme histoire: Réflexions historiographiques, Annales. Histoire, Sciences Sociales, 53(1), 3-39.

Lyall, J. 2006. Pocket protests, rhetorical coercion and micropolitics of collective action in semiauthoritarian regimes, World Politics, 58, 378-412.

Mathieu, L. 2002. Rapport au politique, dimensions cognitives et perspectives pragmatiques dans l'analyse des mouvements sociaux, Revue Française de Science Politique, 52(1), 75100.

McAdam, D. 1982. Political Process and the Development of Black Insurgency 1930-1970. Chicago, University of Chicago Press.

McAdam, D. 1986. Recruitment to high-risk activism: The case of freedom summer, American Journal of Sociology, 92(1), 64-90.

McAdam, D. 1988. Freedom Summer. Oxford, Oxford University Press.

McAdam, D. 1994. Culture and social movements, in New Social Movements: From Ideology to Identity, edited by J. Gusfield, H. Johnston and E. Laraña. Philadelphia, Temple University Press, 36-57.

McAdam, D. 1995. "Initiator" and "spin-off" movements: Diffusion processes in protest cycles, in Repertoires and Cycles of Collective Action, edited by M. Traugott. Durham, Duke University Press, 217-39.

McAdam, D. 1996. Conceptual original, current problems, future directions, in Comparative Perspectives on Social Movements, edited by D. McAdam, J. McCarthy and M. Zald. Cambridge, Cambridge University Press, 23-40.

McAdam D., Tarrow, S. and Tilly C. 2001. Dynamics of Contention. Cambridge, Cambridge University Press.

Oberschall, A. 1973. Social Conflict and Social Movements. Englewood Cliffs, CA, Prentice Hall.

Pacini Hernandez, D. and Garofalo, R. 1999. Hip hop in Havana: rap, race and national identity in contemporary Cuba, Journal of Popular Music Studies, 11-12(1), 18-47.

Passy, F. 2003. Social networks matter: But how? in Social Movements and Networks: Relational Approaches to Collective Action, edited by M. Diani and D. McAdam. Oxford, Oxford University Press, 21-48.

Perry, M. 2004. Rap, Race and Social Transformation in Contemporary Cuba. PhD dissertation. University of Texas, Austin.

Popa J. 2001. "L'impureté" consentie. Entre esthétique et politique : critiques littéraires à Radio Free Europe, Sociétés et représentations 11, 55-75.

Prieto A. 2000. Vanguardia y Masividad, Coordenadas 4 (6), 4-5.

Rowell, J. 2002. Le pouvoir périphérique et le "centralisme démocratique" en RDA, Revue d'Histoire Moderne et Contemporaine, 49(2), 102-24.

Sigman, C. 2009. Clubs Politiques et Pereströ̈ka en Russie: Subversion sans Dissidence. Paris, Karthala.

Siméant, J. 1998. La Cause des Sans Papiers. Paris, Presses de Sciences Po. 
Spires, A. 2011. Contingent symbiosis and civil society in an authoritarian state: Understanding the survival of China's grassroots NGOs. American Journal of Sociology, 117(1): 1-45.

Tarrow, S. 1989. Democracy and Disorder: Protest and Politics in Italy 1965-1975. Oxford, Oxford University Press.

Tarrow, S. 1994. Power in Movement: Social Movements, Collective Action and Politics. Cambridge, Cambridge University Press.

Tilly, C. 1978. From Mobilization to Revolution. Reading, MA, Addison-Wesley Publishing. Yurchak, A. 2006. Everything Was For Ever, Until It Was No More. Princeton, Princeton University Press. 